\title{
ECONOMIC VALUE ADDED (EVA) SEBAGAI PENGUKURAN KINERJA KEUANGAN PADA INDUSTRI TELEKOMUNIKASI SUATU ANALISIS EMPIRIK
}

Trinik Susmonowati

Institut Ilmu Sosial dan Manajemen STIAMI

Email : trinik@stiami.ac.id

\begin{tabular}{l}
\hline ARTIKEL INFO \\
\hline Kata Kunci : Economic \\
Value Added, Kinerja
\end{tabular}

The company's performance has always been measured based on financial ratios for a certain period. Measurement based on financial ratios is very dependent on the accounting treatment used in the preparation of corporate financial statements. The purpose of a company that is only oriented to the achievement of profits as big as when it is no longer relevant today. Therefore the responsibility of the company not only to the shareholders, but to all stakeholders. Performance appraisal of a company is very important that the assessment process must be in line with the effectiveness and efficiency in achieving competitive advantage in the business world. Since the last ten years has developed a new approach in assessing the financial performance of companies known as Economic Value Added (EVA). EVA model comes from the concept of capital cost (cost of capital), which is the risk faced by the company in making investments. The concept of Economic Value Added (EVA) as an alternative to performance measurement based on the value (EVA) is an approach in assessing the performance of the company by paying fair attention to the expectations of funders or investors. EVA is the profit left behind after deducting the capital cost (cost of capital) invested to generate the profit. Positive EVA values can be interpreted that the company's management has created value (creating value). Conversely, if the value of negative EVA means that there is no economic value added into the company. The goal to be achieved by the authors in this study is To determine the financial performance of Telecommunications Company in review of Economic Value Edded (EVA). And To know Which Telecommunication Company that provides better economic value.

This research used qualitative analysis. The qualitative analysis method is used to interpret and analyze the result of EVA calculation, that is to measure the added value of the company by calculating all capital cost, either the capital contribution from the shareholder or from the loan, or the risk faced by the company in making the investment. To measure the company's performance required financial report data in the form of income statement and balance sheet, JCI, stock price and SBI rate data. Data Collection Procedure is the data of financial statements of companies from the telecommunications industry listed on the Indonesia Stock Exchange in the period 2005-2009, obtained from www.idx.co.id. Monthly monthly stock price index (IHSG) monthly from 2005-2009, interest rate of 12 month time deposit from 2005-2009 and stock price data used since 2005.

The results show that only PT Telekomunikasi Indonesia Tbk alone can generate positive EVA, while PT Indosat Tbk and PT Bakrie Telecom Tbk generate negative EVA. Negative EVA values are caused by several factors, among others: because of the significant increase in fuel prices, followed by inflation and rising interest rates affecting people's purchasing power, rising capital costs and operational costs of both companies, the impact of the 2008 global financial crisis that affected on declining stock value and the impact of tariff war between telecommunication companies where telephone tariffs are lower and the decline in long distance call rates affects the telecommunication company's operating revenues. 


\section{PENDAHULUAN}

Keberadaan perusahaan dalam menjalankan kegiatan usahanya selalu diarahkan pada pencapaian tujuan, sehingga perusahaan memerlukan suatu strategi yang tepat untuk mencapai prestasi dan itu dapat ditunjukkan dengan kinerja perusahaan. Kinerja perusahaan selama ini selalu diukur dengan berdasarkan rasio-rasio keuangan selama satu periode tertentu. Pengukuran berdasarkan rasio keuangan ini sangatlah bergantung pada perlakukan akuntansi yang digunakan dalam penyusunan laporan keuangan perusahaan. Berdasarkan perlakuan akuntansi itu seringkali kinerja perusahaan dinilai baik akan tetapi tidak terjadi kenaikan atas kinerja keuangan perusahaan tersebut. Tujuan perusahaan yang hanya berorientasi pada pencapaian laba yang sebesar-besarnya pada saat sudah tidak relevan lagi dimasa sekarang. Karena itu tanggung jawab perusahaan tidak saja kepada para pemegang saham, melainkan kepada seluruh stakeholders. Berdasarkan hal tersebut maka tujuan perusahaan memaksimalkan nilai perusahaan, khususnya bagi perusahaan publik nilai perusahaan selalu dikaitkan dengan nilai saham yang beredar di pasar. Penetapan tujuan yang benar akan sangat berpengaruh kepada proses pencapaian tujuan dan pengukuran kinerja, karena kesalahan pengukuran kinerja akan mengakibatkan kesalahan dalam memberi imbalan atas prestasi yang ada.

Penilaian kinerja terhadap sebuah perusahaan sangat penting bahwa proses penilaian itu harus searah dengan efektifitas dan efisiensi dalam mencapai keunggulan kompetitif di dunia bisnis. Hanya perusahaan yang memiliki kinerja yang unggul yang dapat eksis dan bertahan dalam persaingan bisnis. Dari aspek pembiayaan kemajuan pasar uang (financial market) dan pasar modal (capital market) diharapkan untuk melakukan penilaian validitas kinerja perusahaan. Penilaian kinerja yang tepat menunjang pengambilan keputusan yang baik dan dapat dipertanggung jawabkan serta memberikan jaminan prospektif jangka panjang bagi perusahaan.

Langkah awal sebelum melakukan penilaian kinerja adalah melakukan analisis terhadap laporan keuangan untuk memastikan bahwa laporan keuangan (financial statement) yang di buat telah sesuai dengan standar akuntansi yang dapat dipertanggung jawabkan, karena laporan keuangan perusahaan merupakan salah satu sumber informasi yang penting. Dalam rangka pengukuran kinerja perusahaan biasanya digunakan berbagai macam rasio. Namun rasio keuangan memiliki keterbatasan, karena pengukuran dengan menggunakan rasio tidak dapat mengukur nilai tambah perusahaan yang tercipta dalam periode tertentu.

Sejak sepuluh tahun terakhir telah berkembang suatu pendekatan baru dalam menilai kinerja keuangan perusahaan yang dikenal dengan Economic Value Added (EVA). Istilah EVA pertama kali diperkenalkan oleh Joel Stern dan G.Bernett Stewart III pada tahun 1982. Berbeda dengan pendekatan berbasis resiko tingkat pengembalian tradisional, seperti Return on Investment (ROI), Return on Assets (ROA) dan Return on Equity (ROE) yang diterapkan menurut Pedoman Standar Akuntansi dan Keuangan, model EVA berasal dari konsep biaya modal (cost of capital), yaitu resiko yang dihadapi oleh perusahaan dalam melakukan investasi.

Konsep Economic Value Added (EVA) sebagai alternative untuk pengukuran kinerja yang berdasarkan nilai (value) karena EVA adalah ukuran nilai tambah ekonomis yang dihasilkan oleh perusahaan sebagai akibat dari aktivitas atau strategi manajemen. Dengan adanya EVA, maka pemilik perusahaan hanya akan memberikan imbalan (reward) terhadap aktivitas yang menambah nilai dan membuang aktivitas yang merusak atau mengurangi nilai keseluruhan pada perusahaan.

EVA merupakan pendekatan dalam menilai kinerja perusahaan dengan memperhatikan secara adil ekspektasi penyandang dana atau investor. EVA adalah laba yang tertinggal setelah dikurangi biaya modal (cost of capital) yang di investasikan untuk menghasilkan laba tersebut. Nilai EVA yang positif dapat diartikan bahwa manajemen perusahaan tersebut telah menciptakan nilai (creating value). Sebaliknya apabila nilai EVA negative diartikan bahwa tidak ada nilai tambah ekonomis kedalam perusahaan.

Saat ini telekomunikasi menjadi sebuah bisnis yang sangat menjanjikan, Indonesia menjadi lahan subur bagi perkembangan telekomunikasi karena luas wilayahnya, jumlah penduduk yang banyak serta pasar yang menguntungkan, dimana pola hidup masyarakat Indonesia sangat cepat beradaptasi dengan perkembangan teknologi, dan teknologi komunikasi adalah teknologi yang mempunyai kompabilitas tinggi.

Pesatnya teknologi komunikasi tersebut mendorong berjamurnya perusahaan-perusahaan dibidang telekomunikasi. Perusahaan-perusahaan tersebut saling bersaing untuk dapat menguasai 
pasar. Saat ini di Indonesia terdapat 10 perusahaan yang bergerak di bidang telekomunikasi, yaitu Telkom, Telkomsel, Indosat, Excelcomindo (XL), Hutchison (3), Sinar Mas Telecom (Smart), Sampoerna Telecommunication (Ceria), Bakrie Telecom (Esia), Mobile-8 (Fren), dan Natrindo Telepon Selular (sebelumnya Lippo Telecom). Dalam kompetisi bisnis saat ini bukan hanya untuk mencari pemenang akan tetapi juga untuk meningkatkan performance perusahaan yang menunjukkan seberapa besar kinerja yang telah dicapainya. Berkaitan dengan uraian di atas maka pembahasan dalam thesis ini menekankan pada "Economic Value Added (EVA) Sebagai Pengukuran Kinerja Keuangan Pada Industri Telekomunikasi Suatu Analisis Empirik"

\section{TINJAUAN PUSTAKA}

\section{Pengertian Penilaian Kinerja}

Penilaian kinerja menurut Mulyadi (2000:419) adalah penentuan secara periodic efektifitas operasional suatu organisasi, bagian organisasi dan karyawannya berdasarkan sasaran, standard dan kriteria yang ditetapkan sebelumnya. Karena organisasi pada dasarnya dijalankan oleh manusia, maka penilaian kinerja sesungguhnya merupakan penilaian atas perilaku manusia dalam melaksanakan peran yang mereka mainkan dalam organisasi. Sedangkan penilaian kinerja keuangan adalah penentuan ukuran-ukuran tertentu yang dapat mengukur keberhasilan suatu perusahaan dalam menghasilkan laba.

\section{Tujuan Sistem Pengukuran Kinerja}

Tujuan penilaian kinerja menurut Mulyadi (2000) adalah untuk memotivasi karyawan dalam mencapai sasaran organisasi dan dalam mematuhi standar prilaku yang telah ditetapkan sebelumnya, agar membuahkan tindakan dan hasil yang diinginkan. Standar prilaku dapat berupa kebijakan manajemen atau rencana formal yang dituangkan dalam anggaran. Selain itu tujuan penilaian kinerja adalah untuk dapat menilai apakah tujuan yang telah ditetapkan oleh perusahaan sebagai suatu organisasi dapat tercapai, sehingga mampu memenuhi kepentingan dari pemegang saham, investor dan kreditor. Tujuan dari perusahaan adalah memperoleh laba yang maksimal dan hal ini merupakan daya tarik yang utama bagi pemilik atau investor. Laba perusahaan mengukur partisipasi professional dari setiap unit investasi perusahaan pada periode tertentu. Laba perusahaan merupakan suatu ukuran keberhasilan manajemen. Selain itu investor mempunyai dua kepentingan atas perusahaan yaitu investor tertarik untuk menanamkan modal kepada perusahaan yang berhasil menghasilkan laba yang maksimal dan pada saat yang bersamaan investor juga harus mempertimbangkan konsekuensi atau resiko yang dapat ditimbulkan dari investasi tersebut.

\section{Manfaat Penilaian Kinerja}

Manfaat dari penilaian kinerja perusahaan adalah sebagai berikut:

1. Untuk mengukur prestasi yang dicapai oleh suatu organisasi dalam suatu periode tertentu yang mencerminkan tingkat keberhasilan pelaksanaan kegiatannya.

2. Selain digunakan untuk melihat kinerja organisasi secara keseluruhan, maka pengukuran kinerja juga dapat digunakan untuk menilai kontribusi suatu bagian dalam pencapaian tujuan perusahaan secara keseluruhan.

3. Dapat digunakan sebagai dasar penentuan strategi perusahaan untuk masa yang akan datang.

4. Memberi petunjuk dalam pembuatan keputusan dan kegiatan organisasi pada umumnya dan divisi atau bagian organisasi pada khususnya.

5. Sebagai dasar penentuan kebijaksanaan penanaman modal agar dapat meningkatkan efisiensi dan produktivitas perusahaan.

\section{Tujuan Penilaian Kinerja Perusahaan}

Tujuan penilaian kinerja perusahaan menurut Munawir (2000:31) adalah sebagai berikut:

1. Untuk mengetahui tingkat likuiditas, yaitu kemampuan perusahaan untuk memperoleh kewajiban keuangannya yang harus segera dipenuhi atau kemampuan perusahaan untuk memenuhi keuangannya pada saat ditagih

2. Untuk mengetahui tingkat solvabilitas, yaitu kemampuan perusahaan untuk memenuhi kewajiban 
keuangannya apabila perusahaan tersebut dilikuidasi baik kewajiban keuangan jangka pendek maupun jangka panjang.

3. Untuk mengetahui tingkat rentabilitas atau profitabilitas, yaitu menunjukkan kemampuan perusahaan untuk menghasilkan laba selama periode tertentu.

4. Untuk mengetahui tingkat stabilitas usaha, yaitu kemampuan perusahaan untuk melakukan usahanya dengan stabil, yang diukur dengan mempertimbangkan kemampuan perusahaan untuk membayar beban bunga atas hutang-hutangnya termasuk membayar kembali pokok hutangnya tepat pada waktunya serta kemampuan membayar deviden secara teratur kepada para pemegang saham tanpa mengalami hambatan atau krisis keuangan.

\section{Laporan Keuangan}

Laporan keuangan merupakan gambaran dari suatu perusahaan pada waktu tertentu (biasanya ditunjukkan dalam periode atau siklus akuntansi), yang menunjukkan kondisi keuangan yang telah dicapai suatu perusahaan dalam periode tertentu. Dengan kata lain, laporan keuangan merupakan ringkasan dari suatu proses pencatatan, yaitu merupakan suatu ringkasan dari transaksi-transaksi keuangan yang terjadi selama tahun buku yang bersangkutan. Laporan keuangan yang lengkap biasanya meliputi neraca, laporan laba rugi, laporan perubahan posisi keuangan (yang dapat disajikan dalam berbagai cara seperti, misalnya sebagai laporan arus kas atau laporan arus dana), catatan dan laporan lain serta materi penjelasan yang merupakan bagian integral dari laporan keuangan.

\section{Pengertian Laporan Keuangan}

Menurut Baridwan (2000:17) dalam bukunya mengemukakan, bahwa : "Laporan keuangan merupakan ringkasan dari suatu proses pencatatan, merupakan suatu ringkasan transaksi-transaksi keuangan yang terjadi selama tahun buku yang bersangkutan. Laporan keuangan ini dibuat oleh manajemen dengan tujuan untuk mempertanggungjawabkan tugas-tugas yang dibebankan kepadanya oleh para pemilik perusahaan."

\section{Tujuan Laporan Keuangan}

Menurut Ikatan Akuntan Indonesia dalam buku Standar Akuntansi Indonesia (2002:4) "Tujuan laporan keuangan adalah menyediakan informasi yang menyangkut posisi keuangan, kinerja, serta perubahan posisi keuangan suatu perusahaan yang bermanfaat bagi sejumlah besar pemakai dalam pengambilan keputusan ekonomi."

\section{Karakteristik Laporan Keuangan}

Karakteristik kualitatif laporan keuangan sebagai berikut :

a. Dapat dipahami

Laporan keuangan dinyatakan berkualitas apabila menyajikan informasi keuangan yang mudah dipahami oleh para pemakai. Sajian-sajian tentang informasi keuangan tersebut bersifat transparan, benar, akurat dan akuntabel.

b. Relevan

Sajian-sajian dalam informasi keuangan harus sesuai dengan operasional perusahaan, kebutuhan perusahaan, dan perkembangan perusahaan.

c. Keandalan

Informasi laporan keuangan harus memiliki kualitas andal, bebas dari pengertian yang menyesatkan, kesalahan material, dan dapat diandalkan pemakainya sebagai penyajian yang tulus atau jujur dari yang seharusnya disajikan atau yang secara wajar diharapkan dapat disajikan.

d. Dapat dibandingkan

Pemakai harus dapat membandingkan laporan keuangan perusahaan antara periode untuk megidentifikasi kecenderungan posisi dan kinerja keuangan. Pemakai juga harus dapat membandingkan laporan keuangan antar perusahaan untuk mengevaluasi posisi keuangan, kinerja serta perubahan posisi keuangan secara relatif.

\section{Sifat dan Keterbatasan Laporan Keuangan}

Sifat dan Keterbatasan Laporan Keuangan

e. Laporan keuangan bersifat historis yaitu menyajikan informasi keuangan yang terjadi dimasa lalu. 
Karenanya laporan keuangan tidak dapat dianggap sebagai satu-satunya sumber informasi dalam proses pengambilan keputusan ekonomi.

f. Laporan keuangan bersifat umum, dan bukan dimaksudkan untuk memenuhi kebutuhan pihak tertentu.

g. Proses penyusunan laporan keuangan tidak luput dari penggunaan taksiran dan berbagai pertimbangan.

h. Akuntansi hanya melaporkan informasi yang material. Demikian pula penerapan prinsip akuntansi terhadap suatu fakta atau pos tertentu mungkin tidak dilaksanakan jika hal ini tidak menimbulkan pengaruh yang material terhadap kelayakan laporan keuangan.

i. Laporan keuangan bersifat konservatif dalam menghadapi ketidakpastian, bila terdapat beberapa kemungkinan kesimpulan yang tidak pasti mengenai penilaian suatu pos, maka lazimnya dipilih alternatif yang menghasilkan pendapatan bersih atau nilai aktiva yang paling kecil.

j. Laporan keuangan lebih menekankan pada makna ekonomis suatu peristiwa/transaksi daripada bentuk hukumnya (formalitas).

k. Laporan keuangan disusun dengan menggunakan istilah-istilah teknis, dan pemakai laporan diasumsikan memahami bahasa teknis akuntansi dan sifat dari informasi yang dilaporkan.

1. Adanya pelbagai alternatif metode akuntansi yang dapat digunakan menimbulkan variasi dalam pengukuran sumber-sumber ekonomis dan tingkat kesuksesan antara berbagai usaha.

m. Informasi yang bersifat kualitatif dan fakta yang tidak dapat dikuantifikasikan umumnya diabaikan.

\section{Biaya Modal}

\section{Pengertian Biaya Modal}

Cost of Capital atau biaya modal mempunyai dua makna, tergantung dari sisi investor atau perusahaan. Dari sudut pandang investor cost of capital adalah opportunity cost dari dana yang ditanamkan investor pada suatu perusahaan. (Keown : 1999). Dari sudut pandang perusahaan, cost of capital adalah biaya yang dikeluarkan oleh perusahaan untuk memperoleh sumber dana yang dibutuhkan. Selanjutnya istilah cost of capital digunakan sebagai :

a. discount rate untuk membawa cash flow pada masa mendatang suatu project ke nilai sekarang

b. tarif minimum yang diinginkan untuk menerima project baru

c. biaya modal dalam perhitungan EVA

d. benchmark untuk menaksir tariff biaya pada modal yang digunakan

\section{Komponen Biaya Modal}

Menurut Martin dan Keown (2001) faktor-faktor yang menentukan biaya modal adalah:

a. Keadaan- keadaan umum perekonomian

Faktor ini menentukan permintaan dan penawaran modal dalam perekonomian seperti halnya tingkat inflasi, variabel perekonomian tercermin pada tingkat hasil bebas resiko. Tingkat ini menggambarkan tingkat hasil atas suatu investasi bebas resiko seperti suku bungan surat berharga jangka pendek.

b. Keadaan-keadaan pasar

Jika para investor meningkatkan tingkat hasil minimumnya, ini akan menyebabkan biaya modal serempak meningkat. Jika surat berharga tldak dipasarkan saat para investor ingin menjualnya atau bahkan jika permintaan yang berkesinambungan untuk surat ini ada, namun harga berubah secara signifikan, investor akan memerlukan tingkat hasil yang relatif lebih tinggi. Di lain pihak, bila suatu surat berharga mudah dipasarkan dan harganya relatif stabil para investor akan menghendaki tingkat hasil yang lebih rendah dan biaya modal perusahaan akan rendah.

c. Keputusan operasi dan pembiayaan perusahaan

Resiko atau tingkat perubahan hasil juga diakibatkan oleh keputusan-keputusan yang diambil dalam perusahaan. Resiko yang diakibatkan oleh keputusan ini secara umum dibagi menjadi dua jenis yaitu : Pertama, resiko keuangan adalah meningkatnya variabilitas hasil untuk pemegang saham umum. Tingkat hasil minimum para investor (dan juga biaya modal) akan bergerak dalam arah yang sama. Kedua, resiko bisnis adalah tingkat variasi hasil dari aktiva-aktiva dan 
disebabkan oleh keputusan investasi perusahaan itu.

d. Besarnya pembiayaan.

Bila keperluan pembiayaan suatu perusahaan membesar, bobot biaya modalnya akan meningkat dengan berbagai alasan. Sebagai umpamanya, bila semakin banyak surat berharga yang diterbitkan, biaya pendirian (flotation cost) perusahaan akan mempengaruhi prosentase biaya dari modal untuk perusahaan. Modal merupakan faktor produksi yang dibutuhkan yang merupakan sumber dana jangka panjang bagi perusahaan. Sumber dana jangka panjang sendiri dapat dikelompokkan menjadi dua macam, yaitu sumber dana dari hutang dan dana dari pemilik. Untuk dana dari pemilik dapat berupa saham biasa atau saham preferen.

\section{Biaya Hutang (Cost of Debt)}

Menurut Husnan (2004); "Biaya hutang menunjukkan berapa biaya yang harus ditanggung perusahaan karena perusahaan menggunakan dana yang berasal dari pinjaman". Besarnya tingkat keuntungan yang diminta investor $(\mathrm{Kd})$ tersebut adalah sama dengan tingkat bunga yang menyamakan present value penerimaan dimasa datang yang berupa bunga (i) dan pembayaran pokok bunga pinjaman $(\mathrm{M})$ dengan dana yang diberikan saat ini (harga surat berharga/obligasi $=\mathrm{Po}$ )

Jika obligasi baru dijual dengan harga sama dengan nilai nominal dan tidak ada flotation cost, maka biaya utang sama dengan tingkat bunga. Karena pembayaran bunga merupakan pengurang pajak, maka biaya utang setelah pajak (Ki) harus disesuaikan dengan cara mengalikan (1-pajak) sehingga menjadi :

$K i=K d(1-t)$

Dimana :

$\mathrm{Ki}$

$\mathrm{Kd}$

$\mathrm{T}$

: Biaya hutang setelah pajak

: Biaya hutang sebelum pajak

: tarif pajak penghasilan

\section{Biaya Modal Saham Biasa}

Menurut Weston dan Copeland yang dikutip oleh Iramani (Jurnal Akuntansi dan Keuangan Vol.7 No.1 Mei 2005 p5) menyatakan bahwa; salah satu metode yang dapat digunakan dalam perhitungan biaya modal laba ditahan adalah pendekatan Capital Asset Pricing Model (CAPM), dimana biaya modal laba ditahan adalah tingkat pengembalian atas modal sendiri yang digunakan oleh investor yang terdiri dari tingkat bunga bebas resiko dengan premi resiko pasar dikalikan dengan $\beta$. Secara matematis dapat ditulis :

$K s=R f-(R m-R f) \beta$

Dimana :

Ks = Tingkat pengembalian yang diinginkan investor

$\mathrm{Rf}=$ Tingkat bunga investasi yang diperoleh tanpa resiko (risk free)

$\mathrm{Rm}=$ Hasil pengembalian yang diharapkan dari portofolio pasar $\beta \quad=$ ukuran resiko saham perusahaan

Untuk perhitungan Ks dengan CAPM diperlukan $\mathrm{Rf}, \mathrm{Rm}, \beta$. Dalam perhitungan $\mathrm{Rf}$ (tingkat pengembalian bebas resiko) merupakan tingkat pengembalian yang diperoleh tanpa resiko apapun dan biasanya diwakili oleh tingkat bunga obligasi pemerintah atau Sertifikat Bank Indonesia (SBI) suku bungan SBI dianggap bebas resiko, karena selain diterbitkan oleh pemerintah dalam suku bungan tersebut juga telah termasuk tingkat pengembalian riil dan unsur inflasi. Rm merupakan tingkat pengembalian pada fortofolio pasar yang dinyatakan dengan Indeks Harga Saham Gabungan (IHSG) dengan rumus :

$$
I H S G=\frac{\text { IHSG } t-I H S G t-1}{\text { IHSG } t-1}
$$

Untuk mencari $\beta$ dengan cara menghitung hasil return pada saham t terhadap return pasar yang dalam hal ini adalah IHSG. Besarnya resiko sistematika $\beta$ dari suatu saham tertentu memiliki arti dan dapat dihitung dengan menggunakan rumus : 


\section{$\beta=\frac{\operatorname{Cov}(R m, R f)}{\operatorname{Var} R m}$}

Beta dari saham tersebut dapat dikelompokkan dalam 3 (tiga) kelompok, pertama merupakan saham yang memiliki beta lebih besar dari satu $(\beta>1)$ yang disebut dengan saham agresif, karena saham tersebut mengalami kenaikan lebih cepat dari pada kenaikan rata-rata pasar, begitu juga sebaliknya. Kedua, merupakan saham yang memiliki beta lebih kecil dari satu $(\beta<1)$, yang disebut dengan saham lemah atau saham defensive, karena saham tersebut memiliki fluktuasi return yang lebih. Ketiga merupakan saham yang memiliki beta sama dengan satu $(\beta=1)$, yang disebut dengan saham netral, yaitu saham yang memiliki return yang secara rata- rata sama dengan return saham.

\section{Biaya Modal Rata-rata tertimbang (WACC)}

Menurut Mulyadi (2001:332) : "Biaya modal rata-rata dihitung dengan berbagai modal khusus dengan menggunakan angka penimbang sebesar proporsi tiap-tiap sumber pembelanjaan dalam total investasi yang akan dilakukan"

WACC merupakan rata-rata tertimbang biaya utang dan modal sendiri, menggambarkan tingkat pengembalian investasi minimum untuk mendapatkan tingkat pengembalian yang diharapkan oleh investor. Dengan demikian perhitungannya akan mencakup perhitungan masing-masing komponennya, yaitu biaya utang (cost of debt), biaya modal saham (cost of equity), serta proporsi masing- masing di dalam struktur modal perusahaan.

Rumusan dari Weight average cost of capital adalah :

$$
W A C C=K d(1-t) W d+K e W e
$$

Dimana :

$\mathrm{K}_{\mathrm{d}}=$ Biaya hutang jangka panjang

$\mathrm{Ke}=$ Biaya Pengembalian saham

$\mathrm{W}_{\mathrm{d}}=$ Proporsi hutang dalam struktur modal

$\mathrm{W}_{\mathrm{e}}=$ Proporsi saham dalam struktur modal

$\mathrm{T}=$ Tingkat Pajak Perusahaan

\section{Economic Value Added (EVA)}

\section{Pengertian EVA}

Menurut Young \& Stephen F. O'Byrne (2001: 5) mengemukakan bahwa : 'EVA mengukur perbedaan dalam pengertian keuangan antara pengembalian atas modal perusahaan dan biaya modal." EVA merupakan alat komunikasi yang efektif baik untuk penciptaan nilai yang dapat dijangkau oleh manajer lini yang akhirnya mendorong kinerja perusahaan dan untuk menghubungkan dengan pasar modal. EVA mampu menghitung laba ekonomi yang sebenarnya atau True Economic Profit suatu perusahaan pada tahun tertentu dan sangat berbeda jika dibandingkan dengan laba akuntansi.

Setiap perusahaan tentunya menginginkan nilai Economic Value Added (EVA) akan naik terus-menerus, karena Economic Value Added (EVA) adalah tolok ukur fundamental dari tingkat pengembalian modal (return of capital). Ada beberapa cara untuk meningkatkan nilai Economic Value Added (EVA) perusahaan yaitu (Widayanto, 1993):

a. Meningkatkan keuntungan (profit) tanpa menambah modal

b. Mengurangi pemakaian modal

c. Melakukan investasi pada proyek - proyek dengan tingkat pengembalian tinggi.

\section{Manfaat dari penerapan EVA}

Terdapat beberapa manfaat yang dapat diperoleh perusahaan dalam menggunakan EVA sebagai alat ukur kinerja dan nilai tambah perusahaan. Menurut Tunggal (2008), beberapa manfaat EVA dalam mengukur kinerja perusahaan antara lain : 
1. Dapat digunakan sebagai penilai kinerja perusahaan yang berfokus pada penciptaan nilai (value creation).

2. Dapat meningkatkan kesadaran manajer bahwa tugas mereka adalah untuk memaksimumkan nilai perusahaan serta nilai pemegang saham.

3. Dapat membuat para manajer berfikir dan juga bertindak seperti halnya pemegang saham yaitu memilih investasi yang memaksimumkan tingkat pengembalian dan meminimumkan tingkat biaya modal sehingga nilai perusahaan dapat dimaksimumkan.

4. EVA membuat para manajer agar memfokuskan perhatian pada kegiatan yang menciptakan nilai dan memungkinkan mereka untuk mengevaluasi kinerja berdasarkan kriteria maksimum nilai perusahaan.

5. EVA sebagai motivator perusahaan untuk lebih memperhatikan kebijaksanaan struktur modalnya.

6. EVA dapat digunakan sebagai alat untuk mengidentifikasi proyek atau kegiatan yang memberikan pengembalian yang lebih tinggi dari pada biaya modal.

\section{Keunggulan dan Kelemahan EVA}

Economic Value Added (EVA) sebagai alternatif pengukuran kinerja perusahaan yang relatif baru, memiliki beberapa keunggulan dan kelemahan dalam artikel Siddharta Utama (1997). Keunggulan yang dimiliki Economic Value Added (EVA) antara lain:

1. Konsep Economic Value Added (EVA) merupakan alat ukur yang dapat berdiri sendiri tidak memerlukan adanya suatu perbandingan dengan perusahaan sejenis dalam satu industri, dan tidak perlu pula membuat suatu analisis kecenderungan dengan tahun - tahun sebelumnya.

2. Konsep Economic Value Added (EVA) adalah pengukur kinerja perusahaan yang melihat segi ekonomis dalam pengukurannya, yaitu dengan memperhatikan harapan - harapan pada pemilik modal (kreditur dan pemegang saham) secara adil. Dimana derajat keadilannya dinyatakan dalam ukuran tertimbang dari struktur modal yang ada dan berpedoman pada nilai pasar, bukan nilai buku.

3. Konsep Economic Value Added (EVA) dapat dipakai sebagai tolok ukur dalam pemberian bonus bagi karyawan. Disamping itu Economic Value Added (EVA) juga merupakan tolok ukur yang tepat untuk memenuhi konsep kepuasan stakeholder yakni bentuk perhatian perusahaan kepada karyawan, pelanggan dan pemberi modal (kreditur dan investor).

4. Walaupun konsep Economic Value Added (EVA) berorientasi pada kinerja operasional akan tetapi sangat berpengaruh untuk dipertimbangkan dalam penentuan arah strategis perkembangan portofolio perusahaan.

\section{Strategi Meningkatkan EVA}

Ada beberapa strategi untuk meningkatkan EVA:

a. Strategi penciptaan nilai dengan mencapai pertumbuhan keuntungan (Profitable Growth), hal ini bisa dicapai dengan menambah modal yang diinvestasikan pada proyek dengan tingkat pengembalian tinggi.

b. Strategi penciptaan nilai dengan meningkatkan efisiensi operasi dalam hal ini menaikkan keuntungan tanpa menggunakan tambahan modal.

c. Strategi penciptaan nilai dengan rasionalisasi dan keluar dari bisnis yang tidak menjanjikan (rationalize and exit unrewording business).

Hal ini berarti menarik modal yang tidak produktif dan menarik modal dari aktivitas yang menghasilkan tingkat pengembalian yang rendah dan menghapus unit bisnis yang tidak menjanjikan hasil.

\section{Langkah-langkah Menentukan EVA}

Langkah-langkah yang dilakukan untuk menentukan EVA menurut (Rousana, 1997; 19) :

1. Menghitung biaya modal utang (Cost of Debt)

Dimana :

$$
\begin{aligned}
& K i=K d(1-t) \\
& \mathrm{K}_{\mathrm{i}}=\text { Cost of Debt setelah pajak }
\end{aligned}
$$


$\mathrm{Kd}=$ Tingkat bunga pinjaman

$\mathrm{T}=$ Pajak

2. Menghitung biaya modal saham (Cost of Equity)

3. Menghitung struktur permodalan dari neraca. Struktur modal biasanya terdiri dari utang dan ekuitas, sehingga dicari:

Komposisi utang $=$ rasio utang terhadap jumlah modal Komposisi utang $=$ rasio modal saham terhadap jumlah modal

4. Menghitung biaya modal rata-rata tertimbang (Weighted Average Cost of Capital) $W A C C=K d(1-t) W d+K e W e$

Dimana :

$\mathrm{Kd}=$ Biaya hutang jangka panjang

$\mathrm{Ke}=$ Biaya Pengembalian saham

$\mathrm{Wd}_{\mathrm{d}}=$ Proporsi hutang dalam struktur modal

$\mathrm{W}_{\mathrm{e}}=$ Proporsi saham dalam struktur modal

$\mathrm{T}=$ Tingkat Pajak Perusahaan

Atau :

$$
W A C C=(D X R d)(1-\operatorname{tax})+(E X R e)
$$

Dimana :

$$
\begin{aligned}
& \text { Tingkat Modal }(D)=\frac{\text { Total Hutang }}{\text { Total Hutang dan Equitas }} \times 100 \% \\
& \text { Cost Of Debt }(\text { Rd })=\frac{\text { Beban hutang }}{\text { Total Hutang }} \times 100 \%
\end{aligned}
$$$$
\text { Total Modal Sendiri }(E)=\frac{\text { Total Equitas }}{\text { Total Hutang dan Equitas }} X 100 \%
$$$$
\text { Cost of Equity }(\text { Re })=\frac{\text { EAT }}{\text { Total Equitas }} \times 100 \%
$$

Tingkat tarif Pajak $=\frac{\text { Beban Pajak }}{E B T} \times 100 \%$

\section{Tolok Ukur Penilaian Kinerja Keuangan dalam EVA}

Dalam EVA, penilaian kinerja keuangan diukur dengan ketentuan:

1. Jika EVA > 0, maka kinerja keuangan perusahaan dapat dikatakan baik, karena perusahaan bisa menambah nilai bisnis. Dalam hal ini, karyawan berhak mendapat bonus, kreditur tetap mendapat bunga dan pemilik saham bisa mendapatkan pengembalian yang sama atau lebih dari yang ditanam.

2. Jika EVA = 0, maka secara ekonomis "impas" karena semua laba digunakan untuk membayar kewajiban kepada penyandang dana baik kreditur maupun pemegang saham, sehingga karyawan tidak mendapat bonus hanya gaji.

3. Jika EVA < 0, maka kinerja keuangan perusahaan tersebut dikatakan tidak sehat, karena perusahaan tidak bisa memberikan nilai tambah. Dalam hal ini karyawan tidak bisa mendapatkan bonus hanya saja kreditur tetap mendapat bunga dan pemilik saham tidak mendapatkan 
pengembalian yang sepadan dengan yang ditanam.

\section{Kerangka Konsepsual}

EVA merupakan alat analisis untuk mengukur nilai tambah perusahaan dengan menghitung seluruh biaya modal, baik setoran modal yang berasal dari pemegang saham maupun dari pinjaman, atau resiko yang dihadapi perusahaan dalam melakukan investasi. Perusahan yang akan diteliti adalah perusahaan-perusahaan industri telekomunikasi yang tercatat di BEI yaitu PT. Telekomunikasi Indonesia Tbk, PT. Indosat Tbk, dan PT Bakrie Telecom Tbk.

Untuk mengukur kinerja keuangan diperlukan data laporan keuangan berupa laporan laba rugi dan neraca. Secara sederhana EVA dapat diketahui dari Net Operating Profit After Tax (NOPAT) dikurangi biaya modal. NOPAT merupakan laba bersih ditambah biaya bunga setelah pajak, sedangkan biaya modal (Cost of Capital) menunjukkan besaran kompensasi atau pengembalian modal yang diharapkan oleh investor atas modal yang di investasikan di perusahaan. Modal berasal dari dua sumber dana yaitu ekuitas dan hutang. Nilai NOPAT dapat diperoleh dari laporan laba rugi, sedangkan biaya modal diperoleh dari neraca perusahaan. Setelah diketahui nilai EVA, maka dapat dilihat kinerja perusahaan baik atau tidak. Nilai tersebut merupakan referensi bagi beberapa pihak yang berkepentingan untuk mengambil keputusan.

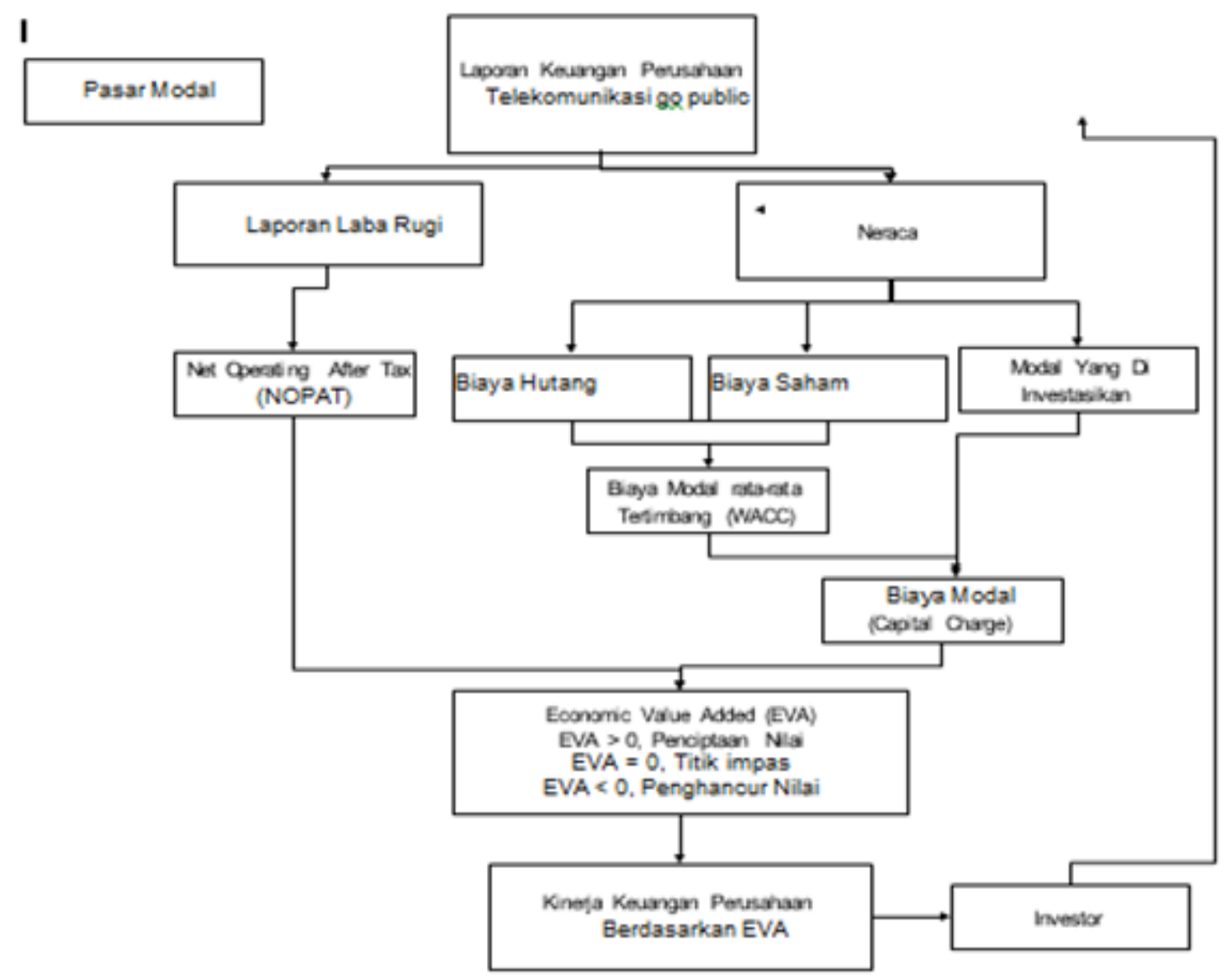

Gambar 1, Keranglea Pemikiran Penelitian

\section{METODE PENELITIAN}

\section{Desain Penelitian}

Ditinjau berdasarkan tujuan penelitian, desain penelitian yang dilakukan desain penelitian 
yang digunakan adalah desain penelitian eksploratif yang bertujuan untuk mengungkap secara luas dan mendalam tentang sebab-sebab dan hal-hal yang mempengaruhi terjadinya sesuatu, yaitu menggambarkan dan menjelaskan fenomena mengenai kinerja keuangan perusahaan tiga perusahaan telekomunikasi terbuka yang terdaftar di Bursa Efek Indonesia, yaitu PT Bakrie Telecom, Tbk, PT Indosat, Tbk, dan PT Telekomunikasi Indonesia Tbk. Data mengenai kinerja keuangan perusahaanperusahaan telekomunikasi tersebut dianalisis dengan menggunakan perhitungan Economic Value Added (EVA).

EVA merupakan alat analisis untuk mengukur nilai tambah perusahaan dengan menghitung seluruh biaya modal, baik setoran modal dari pemegang saham maupun dari pinjaman, atau risiko yang dihadapi perusahaan dalam melakukan investasi. Untuk mengukur kinerja perusahaan diperlukan data laporan keuangan berupa laporan laba rugi dan neraca. Secara sederhana EVA dapat diketahui dari Net Operating After Tax (NOPAT) dikurangi biaya modal. NOPAT merupakan laba bersih ditambah biaya bungan setelah pajak, sedangkan biaya modal (Cost Of Capital) menunjukkan besarnya kompensasi atau pengembalian modal yang dituntut oleh investor atas modal yang diinvestasikan di perusahaan. Modal berasal dari dua sumber dana, yaitu equitas dan utang. Nilai NOPAT dapat diperoleh dari laporan laba rugi, sedangkan biaya modal dapat diperoleh dari neraca perusahaan.

Ditinjau berdasarkan tempat/sumber data, desain penelitian yang digunakan adalah dengan membaca buku-buku dan artikel yang menunjang untuk kepentingan landasan teori dalam mendukung analisis yang dilakukan, laporan keuangan perusahaan untuk kebutuhan analisis, data Indeks Harga Saham Gabungan (IHSG), harga saham perusahaan dan data suku bunga SBI.

\section{Populasi dan Sampel}

Populasi penelitian adalah perusahaan-perusahaan dalam kelompok industry telekomunikasi yang terdaftar di Bursa Efek Indonesia pada tahun 2005 - 2009. Pemilihan sampel penelitian didasarkan pada metode nonprobability sampling tepatnya metode purposive sampling yaitu teknik penentuan sample dengan menggunakan pertimbangan tertentu. Adapun kriteria yang digunakan untuk memilih sampel pada penelitian ini adalah sebagai berikut. (1) Perusahaan sampel terdaftar di Bursa Efek Indonesia tahun 2005 - 2006 dalam kelompok industri telekomunikasi yang menerbitkan laporan tahunan (annual report) secara berturut-turut. (2) Perusahaan sampel mempunyai laporan keuangan yang berakhir 31 Desember dan menggunakan rupiah sebagai mata uang pelaporan. (3) Perusahaan sampel memiliki semua data yang diperlukan secara lengkap. Berdasarkan kriteria tersebut, diperoleh sampel sebanyak 3 perusahaan yaitu PT Bakrie Telecom, Tbk, PT Indosat, Tbk, dan PT Telekomunikasi Indonesia Tbk pada periode 2005-2009. Data diperoleh dengan mengakses website www.idx.co.id

\section{Instrumen Penelitian}

Instrumen (alat) penelitian adalah teknik pengukuran dengan menggunakan perhitungan Economic Value Added (EVA), yaitu untuk mengukur nilai tambah perusahaan dengan menghitung seluruh biaya modal, baik setoran modal dari pemegang saham maupun dari pinjaman, atau risiko yang dihadapi perusahaan dalam melakukan investasi. Untuk mengukur kinerja perusahaan diperlukan data laporan keuangan berupa laporan laba rugi dan neraca, IHSG, harga saham perusahaan dan data suku bunga SBI.

\section{Prosedur Pengumpulan Data}

Data yang dikumpulkan adalah data laporan keuangan perusahaan dari industri telekomunikasi yang tercatat di Bursa Efek Indonesia pada periode 2005-2009, yang diperoleh dari www.idx.co.id. Data bulanan indeks harga saham gabungan (IHSG) bulanan dari tahun 2005-2009, tingkat suku bunga deposito berjangka 12 bulan dari tahun 2005-2009, data harga saham yang dipergunakan sejak tahun 2005 yang diharapkan dapat menggambarkan tingkat risiko saham perusahaan telekomunikasi. Sebagai penunjang digunakan data yang relevan dengen penelitian yang diperoleh dari literatur, koran, jurnal, majalah, laporan penelitian dan publikasi elektronik.

\section{Metode Analisis Data}

Metode analisis yang digunakan dalam penelitian ini adalah metode analisis kualitatif 
kuantitatif. Metode analisis kualitatif digunakan untuk menginterpretasikan dan menganalisis hasil dari perhitungan EVA. Apakah nilai EVA yang dihasilkan positif atau negatif. Dengan hasil itu dapat diketahui apakah perusahaan menghasilkan nilai bahwa tingkat pengembalian yang dihasilkan melebihi tingkat biaya modal atau tingkat pengembalian kepada investor atau menghancurkan nilai, yaitu berkurangnya nilai perusahaan sebagai akibat tingkat pengembalian yang lebih rendah daripada tingkat pengembalian yang dikembalikan kepada investor.

\section{PEMBAHASAN}

\section{Perkembangan Perusahaan}

\section{PT. Telekomunikasi Indonesia Tbk}

PT. Telkomsel merupakan sebuah operator telekomunikasi seluler terbesar di Indonesia. Dalam menjalankan bisnisnya Telkomsel menyediakan jasa telekomunikasi seluler jenis GSM yaitu jenis operator seluler yang global di seluruh dunia. Telkomsel mempunyai jumlah pelanggan 38,9 juta yang tersebar diseluruh Indonesia yang merupakan 55\% dari pasar telekomunikasi Indonesia.

Pertumbuhan pelanggan telepon tetap kabel Telkom dalam lima tahun terakhir minus $0,9 \%$, dari 8,7 juta (2005) menjadi 8,4 juta (2009). Namun, pelanggan telepon tetap nirkabel meningkat hingga 39\% dari 4,1 juta (2005) menjadi 15,1 juta (2009). Untuk layanan seluler Telkomsel masih mampu mempertahankan posisi sebagai pemimpin pasar dengan total pelanggan lebih dari 81 juta dan pangsa pasar mencapai $49 \%$. (sumber : majalah Swasembada)

Terjadi kenaikan atas Aktiva lancar yang cukup significant dari tahun 2005 ke tahun 2006 yaitu sebesar 35.09\%. Kenaikan aktiva lancar di tahun 2007 hanya sebesar $14.78 \%$, dan pada tahun 2008 terjadi penurunan aktiva sebesar 8.48\% dibanding tahun 2007. Dilihat dari total aktiva setiap tahun PT. Telekomunikasi Indonesia Tbk cenderung mengalami peningkatan.

Laba bersih yang dihasilkan oleh PT Telekomunikasi Indonesia Tbk cenderung mengalami kenaikan walaupun pada tahun 2008 sempat mengalami penurunan laba bersih sebesar $17.40 \%$ dibandingkan dengan tahun 2007, kondisi ini dikarenakan pendapatan usaha PT Telekomunikasi Indonesia Tbk pada tahun 2008 tidak mengalami kenaikan yang baik, hanya mengalami kenaikan sebesar $2.10 \%$ dari tahun sebelumnya, sementara beban usaha meningkat sebesar $16.43 \%$. Namun di akhir tahun 2009 laba perusahaan ini kembali mengalami kenaikan sebesar $6.71 \%$.

\section{PT. Indosat Tbk}

PT Indonesian Satellite Corporation Tbk. (ISAT) didirikan pada tahun 1967 sebagai Perusahaan Modal Asing, dan memulakan operasinya pada tahun 1969. Pada tahun 1980 ISAT menjadi BUMN dimana seluruh sahamnya dimiliki oleh Pemerintah Indonesia. Hingga sekarang, ISAT menyediakan layanan telekomunikasi internasional seperti SLI, selular, internet dan layanan transmisi TV antar bangsa.

ISAT adalah perusahaan telekomunikasi dan multimedia terbesar kedua di Indonesia untuk jasa seluler ( Satelindo, IM3 dan Star One) setelah Telkom. Saat ini, komposisi kepemilikan saham Indosat adalah: publik adalah sekitar 44,91\%, Qtel memiliki 40,8\%, dan Pemerintah sendiri memiliki saham ISAT sebanyak $14,29 \%$ dimana saham ISAT termasuk blue chip.

\section{a. Kondisi Keuangan Perusahaan}

Berdasarkan Neraca PT Indosat Tbk tahun 2005-2009, terdapat penurunan aktiva lancar di tahun 2006 dibandingkan dengan tahun 2005, penurunan aktiva lancar tersebut mencapai 24.73\%. dilihat dari sisi aktiva lancar PT Indosat cenderung mengalami penurunan, dilihat dari total aktiva pun kenaikan yang cukup baik hanya terjadi pada tahun 2007 yaitu meningkat $32.36 \%$ dibandingkan dengan tahun 2006. Begitupun jika dilihat dari total kewajiban, pada tahun 2007 total kewajiban PT Indosat mengalami kenaikan cukup besar yaitu 51.19\% dibandingkan dengan tahun 2007. Sepanjang tahun 2005-2007, dari lima indikator keuangan utama (sales, operating profit, Net Income, Total Equity dan Total Assets) perusahaan ISAT mampu meningkatkan sales dengan rata-rata pertumbuhan per tahun sebesar $19,50 \%$, bahkan pada tahun 2007 perusahaan berhasil mencatat pertumbuhan sales tertinggi 34,72\% dibandingkan dengan 2 tahun terakhir yang berkisar antara 5\%- 28\%. Profitabilitas perusahaan juga meningkat sebesar 44.82\% pada tahun 2007. Dampak krisis ekonomi global dan perang tarif pada periode 2008- 
2009 berdampak terhadap turunnya laba perusahaan dan meningkatnya total kewajiban PT Indosat.

\section{PT Bakrie Telecom Tbk.}

PT. Bakrie Telecom,tbk (BEJ: BTEL) adalah perusahaan operator telekomunikasi berbasis CDMA diIndonesia. Bakrie Telecom memiliki produk layanan dengan nama produk Esia serta Wifone. Perusahaan ini sebelumnya dikenal dengan nama PT Ratelindo, yang didirikan pada bulan Agustus 1993, sebagai anak perusahaan PT Bakrie \& Brothers Tbk yang bergerak dalam bidang telekomunikasi di DKI Jakarta, Banten dan Jawa Barat berbasis Extended Time Division Multiple Access (ETDMA). Pada bulan September 2003, PT Ratelindo berubah nama menjadi PT Bakrie Telecom, yang kemudian bermigrasi ke CDMA2000 1x, dan memulai meluncurkan produk Esia. Saat ini produk Esia hanya dapat dinikmati di Jakarta, Banten, dan Jawa Barat. Pada tahun 2006, Bakrie Telecom telah go-public dengan mendaftarkan sahamnya dalam Bursa Efek Jakarta. Pada 17 September 2007, pemerintah Indonesia memberikan lisensi atas jaringan tetapsambungan langsung internasional Indonesia kepada Bakrie Telecom.

\section{a. Kondisi Keuangan Perusahaan}

Berdasarkan laporan keuangan dari sisi aktiva lancar PT Bakrie Telecom Tbk terjadi kenaikan pada tahun 2007 dan 2008 yaitu naik sebesar 75.76\% di tahun 2007 dan meningkat sebesar $149.01 \%$ ditahun 2008. Dilihat dari total aktiva, kenaikan total aktiva yang cukup besar terjadi pada tahun 2007 dan 2008.

Dilihat dari laporan laba rugi periode 2006-2009, hanya pada tahun 2007 saja PT Bakrie Telecom Tbk mengalami kenaikan atas laba yaitu naik sebesar $98.50 \%$, namun di tahun 2008 dan 2009 laba perusahaan ini mengalami penurunan. Penurunan laba pada tahun 2008 dilihat dari laporan laba rugi yang disajikan dikarenakan karena terjadinya peningkatan pada beban lain-lain yang meningkat sampai dengan 103.43\% dibandingkan dengan tahun 2007.

\section{Pembahasan Pajak Penghasilan}

Pajak penghasilan adalah pajak yang dibebankan pada penghasilan perorangan, perusahaan atau badan hukum lainnya. Pajak penghasilan bisa diberlakukan progresif, proporsional, atau regresif. Pengertian penghasilan dalam Undang-undang PPh tidak memperhatikan adanya penghasilan dari sumber tertentu, tetapi pada adanya tambahan kemampuan ekonomis. Tambahan kemampuan ekonomis yang diterima atau diperoleh Wajib Pajak merupakan ukuran terbaik mengenai kemampuan Wajib Pajak tersebut untuk ikut bersama-sama memikul biaya yang diperlukan pemerintah untuk kegiatan rutin dan pembangunan.

Tarif WP Badan :

Berdasarkan ketentuan UU No. 17 tahun 2000 (Berlaku sampai dengan 31 Desember 2008)

\begin{tabular}{|c|c|}
\hline Lapisan Penghasilan & Tariff \\
\hline s.d Rp. 50.000.000,- & $10 \%$ \\
\hline Di atas Rp. 50.000.000- Rp. 100.000.000,- & $15 \%$ \\
\hline Di atas Rp. 100.000.000,- & $30 \%$ \\
\hline
\end{tabular}

Keputusan Perubahan (berlaku mulai 1 Januari 2009)

a. Tariff tunggal $30 \%$

b. Diturunkan menjadi $28 \%$ pada tahun 2009 , dan menjadi $25 \%$ pada tahun 2010

Untuk WP Badan Masuk Bursa diberikan tariff 5\% lebih rendah dari tariff yang berlaku.

\section{Perhitungan Suku Bunga}

Untuk perhitungan suku bunga digunakan suku bunga SBI karena dianggap bebas resiko, selain diterbitkan oleh pemerintah, suku bunga tersebut juga termasuk tingkat pengembalian riil dan unsur inflasi. Suku bunga SBI yang digunakan adalah suku bunga SBI bulanan dalam kurun waktu 
2005-2009.

\section{Analisis Cost Of Debt (Kd)}

Biaya hutang merupakan biaya yang harus ditanggung perusahaan karena menggunakan modal yang berasal dari pinjaman.

\section{PT Telekomunikasi Indonesia Tbk}

Dari laporan keuangan tahun 2005-2009 PT Telekomunikasi Indonesia Tbk memiliki prosentasi biaya bunga terhadap utang yang cenderung mengalami kenaikan setiap tahunnya, dimulai dari 6.18\% di tahun 2005 meningkat sampai dengan 9.56\% ditahun 2009, hal ini disebabkan karena terjadi kenaikan biaya bunga di tahun 2009 dibandingkan dengan tahun 2008 dimana biaya bunga naik mencapai 26,4\% yaitu dari Rp. 1.58 triliun menjadi Rp. 2 triliun di tahun 2009.

PT Telkom juga mengalami kenaikan atas utang jangka panjangnya di tahun 2008 dan 2009, setelah selama 3 tahun sebelumnya yaitu tahun 2005- 2007 terjadi penurunan atas utang jangka panjangnya. Pada tahun 2008 utang jangka panjang mengalami kenaikan sebesar $10.52 \%$ dibandingkan tahun 2007 dan di tahun 2009 mengalami kenaikan 3.25\% dibandingkan tahun 2008.

\section{PT Indosat Tbk}

Dari laporan keuangan tahun 2005 - 2009, PT Indosat Tbk memiliki prosentase biaya bunga terhadap utang yang berfluktuasi setiap tahunnya. Prosentase biaya bunga terhadap utang yang cukup besar terjadi pada tahun 2006, dimana prosentasenya mencapai 10.39\%. Pada tahun 2007-2009 prosentase biaya bunga terhadap utang jangka panjang PT Indosat Tbk mengalami penurunan, walaupun jika dilihat dari biaya bunga tiap tahunnya mengalami peningkatan dari Rp. 1.4 triliun sampai mencapai Rp. 1.8 triliun di tahun 2009, kenaikan biaya bunga tersebut diimbangi dengan kenaikan utang jangka panjang perusahaan ini dari Rp. 16.8 triliun ditahun 2007 dan menjadi Rp. 23.6 triliun ditahun 2009.

\section{PT Bakrie Telecom Tbk}

Dari laporan keuangan tahun 2006 - 2009, PT Bakrie Telecom Tbk memiliki prosentase biaya bunga terhadap hutang yang berfluktuasi setiap tahunnya. Kenaikan yang cukup besar terjadi di tahun 2008 dimana prosentase biaya bunga terhadap utang jangka panjang PT Bakrie Telecom Tbk meningkat mencapai 5.50\%, hal ini disebabkan kenaikan biaya utang sebesar $46.6 \%$ di tahun 2008 dibandingkan dengan tahun 2007 tidak sebanding dengan kenaikan utang jangka panjangnya yang hanya mengalami kenaikan sebesar 5.36\%.

\section{Analisis Cost of Common Equity (Ke)}

Biaya modal sendiri terjadi karena adanya penggunaan sumber modal sendiri yang terdiri dari laba ditahan dan saham biasa. Biaya modal sendiri tercermin dari tingkat pengembalian yang diharapkan oleh investor atas investasi yang dilakukannya yang dihitung dengan menggunakan pendekatan CAPM.

\section{PT Telekomunikasi Indonesia Tbk}

Berdasarkan data bulanan harga saham periode 2005-2009, PT Telekomunikasi Indonesia Tbk memiliki beta $(\beta)$ berturut-turut adalah $0.88 ; 0,86 ; 0,53 ; 0,67$; dan 0,50 . Hal ini menunjukkan PT Telekomunikasi Indonesia Tbk memiliki resiko yang lebih kecil daripada resiko pasar karena $\beta$ kurang dari $1(\beta<1=$ resiko yang lebih kecil dari resiko pasar) yang disebut dengan saham lemah atau saham defensive, karena saham tersebut memiliki fluktuasi return yang lebih. Biaya modal saham (Ke) PT Telekomunikasi Indonesia Tbk pada tahun 2008 mengalami penurunan yang cukup tajam yaitu mencapai $-0.69 \%$ hal ini disebabkan oleh karena pada tahun 2008 terjadi krisis keuangan global dimana IHSG pada tahun tersebut mengalami penurunan hingga -0.051 dan SBI pada triwulan terakhir tahun 2008 mencapai $9.5 \%$.

\section{PT Indosat Tbk}

Berdasarkan data bulanan harga saham periode 2005-2009. PT Indosat tbk memiliki beta ( $\beta$ ) 
berturut-turut adalah 1.030; 1.012; 0.808; 0.297; dan 1.065. pada tahun 2005, 2006 dan 2009 PT Indosat Tbk memiliki $\beta$ lebih dari $1(\beta>1)$ yang disebut dengan saham agresif, karena saham tersebut mengalami kenaikan lebih cepat dari pada kenaikan rata-rata pasar, yang berarti PT Indosat Tbk memiliki resiko yang lebih besar dari resiko pasar. Sedangkan pada tahun 2007 dan $2008 \beta$ PT Indosat kurang dari $1(\beta<1)$ yang disebut dengan saham lemah atau saham defensive, karena saham tersebut memiliki fluktuasi return yang lebih pada tahun tersebut PT Indosat Tbk memiliki resiko yang lebih kecil daripada resiko pasar. Biaya modal saham (Ke) PT Indosat Tbk pada periode 2005-2009 berturut- turut adalag $1.15 \% ; 3.77 \% ; 4.63 \% ; 4.58 \% ; 5,50 \%$.

\section{PT Bakrie Telecom Tbk}

Berdasarkan data bulanan harga saham periode 2006 - 2009 PT Bakrie Telecom Tbk memiliki beta $(\beta)$ berturut-turut adalah $0.726 ; 1.203 ; 1.247 ; 2.740$, dari rata-rata nilai $\beta$ yang diperoleh oleh PT Bakrie Telecom Tbk menunjukkan nilai diata 1 (satu) $(\beta>1)$ yang disebut dengan saham agresif, karena saham tersebut mengalami kenaikan lebih cepat dari pada kenaikan rata-rata pasar yang artinya PT Bakrie Telecom Tbk memiliki resiko yang lebih besar dari resiko pasar. Biaya modal saham (Ke) PT Bakrie Telecom Tbk pada tahun 2008 saham seperti PT Telekomunikasi Indonesia Tbk, dimana dampak krisis global memberikan pengaruh yang cukup terhadap biaya modal PT Bakrie Telecom Tbk. Pada tahun 2008 biaya modal PT Bakrie Telecom Tbk menurun sampai dengan $-8.51 \%$.

\section{Analisis WACC}

Pada perusahaan yang mengalami kenaikan atau penurunan nilai WACC, dapat disebabkan atas dua factor yaitu menurunnya atau meningkatnya nilai biaya hutang (cost of debt) atau disebabkan menurun atau meningkatnya biaya ekuitas (cost of equity). Sedangkan proporsi hutang dan proporsi ekuitas sebagai variable yang tidak berpengaruh, karena hasil komposisi dari jumlah modal (hutang ditambah ekuitas). Secara keseluruhan nilai WACC mempengaruhi besar kecilnya EVA yang diperoleh perusahaan, karena WACC sebagai pengali atas modal (Capital Charges).

Dari nilai WACC yang di peroleh oleh ketiga perusahaan telekomunikasi tersebut diatas dapat dilihat bahwa ketiga perusahaan memiliki nilai WACC yang berfluktuasi naik dan turun. Untuk PT Telekomunikasi Indonesia tbk, nilai WACC mengalami penuruan yang cukup significant yaitu dari $3.76 \%$ pada tahun 2007 menjadi $0.99 \%$ pada tahun 2008 begitu juga penurunan nilai WACC pada PT Bakrie Telecom tbk, yang turun dari $2.35 \%$ pada tahun 2007 menjadi $-387 \%$ pada tahun 2008 yang disebabkan karena meningkatnya utang jangka panjangnya dan menurunnya nilai biaya pengembalian saham $(\mathrm{Ke})$ kedua perusahaan tersebut.

\section{Analisis NOPAT}

Besar kecilnya NOPAT akan dipengaruhi oleh laba usaha dan beban pajak yang ditanggung oleh perusahaan. Jika laba operasi lebih tinggi dari beban pajak maka nilai NOPAT akan tinggi dan berdampak pada besarnya nilai EVA. Sebaliknya bila laba operasi lebih rendah dari beban pajak rendah, maka nilai NOPAT akan rendah dan dapat menimbulkan EVA yang negative bagi perusahaan.

Perhitungan NOPAT untuk perusahaan industri telekomunikasi dapat dapat dilihat bahwa PT Telekomunikasi Indonesia memiliki hasil NOPAT yang selalu positif walaupun di tahun 2008 nilai NOPAT PT Indosat mengalami penurunan. Sedangkan untuk PT Indosat tbk, nilai NOPAT yang diperoleh trend nya naik turun dan puncaknya pada tahun 2009 nilai NOPAT PT Indosat tbk, bernilai negative dimana biaya bunga lebih besar dari laba bersih yang di hasilkan oleh PT Indosat tbk. Untuk PT Bakrie Telecom tbk, nilai NOPAT yang dihasilkan sejak tahun 2006 cenderung mengalami penurunan, dampak krisis ekonomi global sangat terasa pada perusahaan ini penurunan yang sangat besar pada tahun 2008, dan puncaknya pada tahun 2009 nilai NOPAT yang dihasilkan oleh perusahaan ini adalah negative yang disebabkan tingginya biaya bunga yang melebihi laba bersih perusahaan.

\section{Analisis Invested Capital}

Nilai invested capital sangat mempengaruhi nilai EVA, karena Invested Capital sebagai pengali atas WACC yang akan menghasilkan Capital Charges, semakin besar nilai Invested Capital, maka akan semakin besar nilai capital charges sebagai pengurang NOPAT. Dari nilai invested capital ketiga perusahaan telekomunikasi diatas terlihat bahwa ketiga perusahaan mengalami kenaikan nilai 
invested capitalnya yang berarti meningkatnya jumlah modal yg di investasikan oleh ketiga perusahaan tersebut setiap tahunnya.

\section{Analisis Capital Charges}

Sebagai pengurang NOPAT, Capital Charges sangat mempengaruhi nilai EVA. Jika Capital Charges lebih besar daripada nilai NOPAT akan menghasilkan nilai EVA yang negative. Hal ini menandakan nilai perusahaan berkurang sebagai akibat dari tingkat pengembalian yang dihasilkan lebih rendah daripada tingkat pengembalian yang dituntut oleh investor. Sebaliknya, jika nilai capital charges lebih kecil daripada nilai NOPAT, maka akan menghasilkan nilai EVA yang positif. Hal ini menandakan bahwa tingkat pengembalian yang diharapkan melebihi tingkat biaya modal. Dari nilai cost of capital ketiga perusahaan telekomunikasi diatas pada tahun 2008 PT Telekomunikasi Indonesia tbk dan PT Bakrie Telecom mengalami penurunan nilai cost of capital yang disebabkan oleh nilai WACC yang juga mengalami penurunan. Untuk PT Indosat nilai cost of capital cenderung mengalami kenaikan.

\section{Analisis Economic Valued Added}

Analisis ini untuk mengetahui kinerja perusahaan dengan memfokuskan penilainannya kepada nilai tambah dengan memperhatikan semua biaya modal termasuk didalamnya biaya hutang, biaya saham biasa, dan total capital serta laba operasi setelah pajak.

\section{PT Telekomunikasi Indonesia Tbk}

Perusahaan memiliki nilai rata-rata biaya modal tertimbang (WACC) selama periode 20052009 adalah masing-masing $2.15 \%, 3.00 \%, 3.67 \%, 0.99 \%$ dan $4.01 \%$ penurunan nilai WACC pada tahun 2008 disebabkan adanya penurunan pada pengembalian saham pada tahun 2008 akibat krisis global. Pada tahun 2008, perusahaan juga mengalami penurunan atas laba bersih setelah pajak (NOPAT) sebesar 21\% dari tahun sebelumnya yaitu Rp. 11.420.853,- pada tahun 2007 menjadi Rp. 9.037.652,- pada tahun 2008. Penurunan ini terjadi karena terjadi penurunan atas laba bersih perusahaan dan kenaikan atas biaya bunga. Modal yang diinvestasikan (IC) perusahaan pada tahun 2009 mengalami peningkatan. Peningkatan ini terjadi karena adanya kenaikan pada utang jangka panjang dan equitas mencapai $13,63 \%$ yang cukup significant.

Berdasarkan hasil perhitungan EVA selama periode penelitian, PT Telkom memliki nilai EVA yang positif dapat dilihat pada table 9. Nilai EVA selama tahun 2005 -2009 adalah positif, yang berarti perusahaan memiliki kinerja keuangan yang sehat sehingga dapat memenuhi harapan investor dan kreditur. Melihat kinerja perusahaan melalui pendekatan EVA sangatlah penting bagi investor, yang juga sebagai pemegang saham, untuk mengetahui kemampuan perusahaan memberdayakan kapitalnya, di samping laba perusahaan. Sebab, bagaimanapun, EVA perusahaan merupakan salah satu parameter dalam memutuskan berinvestasi.

Dengan EVA para pengelola perusahaan dengan sadar menciptakan value added karena inilah yang akan diapresiasi para pemegang saham atau investor. Makin besar value added yang mereka ciptakan, potensi keuntungan bagi investor juga makin tinggi. Jika perusahaan selalu bisa memenuhi harapan pemegang saham, nilai perusahaan akan terus naik. Angka EVA ini hanya sebagai indikasi awal untuk checking, terutama dari segi modal yang ditanamkan untuk menjalankan bisnis

\section{PT Indosat Tbk}

Perusahaan memiliki nilai rata-rata biaya modal tertimbang (WACC) yang berfluktuasi selama periode 2005-2009, pada tahun 2006 dan 2008 nilai WACC meningkat dari tahun sebelumnya, hal ini disebabkan karena pada tahun 2006 terjadi kenaikan atas biaya pengembalian saham perusahaan sedangkan pada tahun 2008 disebabkan karena terjadi kenaikan atas proporsi utang dalam struktur modal.

Perusahaan selama periode 2005-2009 memiliki nilai laba bersih setelah pajak (NOPAT) yang berfluktuasi cukup significant. Dimulai pada tahun 2006 dimana laba bersih yang diperoleh oleh PT Indosat Tbk mengalami penurunan sebesar 13\% yaitu dari Rp. 1.623.481.000.000 pada tahun 2005 turun menjadi Rp. 1.410.093.000.000 di tahun 2006. Diperburuk lagi akibat dampak krisis global pada tahun 2008 yang menyebabkan laba perusahaan kembali mengalami penuruan mencapai $8 \%$ dari tahun 2007 yang juga dibarengi dengan kenaikan biaya bunga sampai dengan 30\%. Hingga pada akhir 
tahun 2009, nilai NOPAT PT Indosat Tbk bernilai negative oleh karena laba turun mencapai 20\% yang nilainya lebih tinggi dari nilai biaya bunga perusahaan.

Modal yang diinvestasikan (IC) perusahaan cenderung mengalami kenaikan setiap tahunnya. Kenaikan ini disebabkan karena naiknya utang jangka panjang perusahan pada tahun 2007 yang naik mencapai 39.7\% dan pada tahun 2008 meningkat kembali menjadi 38.7\%. Kenaikan nilai utang perusahaan tidak diimbangi dengan kenaikan nilai equitas. Berdasarkan hasil perhitungan EVA selama periode penelitian, PT Indosat memiliki EVA yang negative, jika dilihat dari tolak ukur EVA, apabila perusahaan memiliki EVA $<0$ artinya perusahaan tidak mampu membayarkan kewajiban kepada para penyandang dananya atau kreditur sebagaimana nilai yang diharapkan ekspektasi rate of return tidak dapat tercapai. Selama periode penelitian jika dilihat dari laba yang diperoleh PT Indosat Tbk selalu menghasilkan laba. Ketika perusahaan aktif melakukan investasi baru, yang membuat EVA-nya negatif, atau bahkan merugi, investor tidak melihat bahwa perusahaan itu jelek. Yang terpenting, apakah ke depan perusahaan terus-menerus tumbuh atau tidak. PT Indosat Tbk jika dilihat dari sisi equitas dan utang jangka panjang mengalami kenaikan yang cukup significant yaitu pada tahun 2007 dan 2008, jika kenaikan itu adalah untuk tambahan investasi, akan memberikan nilai tambah kepada investor tidak pada tahun berjalan tetapi pada masa yang akan datang. EVA negatif menunjukkan bahwa perusahaan tidak dapat mendapatkan uang karena COC lebih tinggi daripada return yang dihasilkan.

\section{PT Bakrie Telecom Tbk}

Perusahaan memiliki nilai rata-rata biaya modal tertimbang (WACC) selama periode 20062009 berturut-turut $4.44 \%, 2.35 \%,-3.87 \%$ dan 2.34\%. penurunan WACC pada tahun 2007 disebabkan kenaikan biaya utang jangka panjang dan kenaikan proporsi utang. Pada tahun 2008 nilai WACC PT Bakrie Telecom Tbk bernilai negative, disebabkan karena penurunan atas nilai pengembalian saham. Perusahaan selama periode 2006-2009 mengalami penurunan nilai laba operasi bersih setelah pajak (NOPAT) setiap tahunnya. Pada tahun 2007 laba perusahaan naik mencapai 98\% tetapi biaya bunga perusahaan juga ikut meningkat tajam mencapai 600\%. Finalnya pada tahun 2009 laba perusahaan mengalami penurunan sebesar $29 \%$ namun biaya bunga mengalami kenaikan $17 \%$ sehingga nilai NOPAT yang dihasilkan menjadi negative pada tahun 2009. Berdasarkan hasil perhitungan EVA selama periode penelitian, PT Bakrie Telecom Tbk memiliki EVA yang negative, jika dilihat dari tolak ukur EVA, apabila perusahaan memiliki EVA $<0$ artinya perusahaan tidak mampu membayarkan kewajiban kepada para penyandang dananya atau kreditur sebagaimana nilai yang diharapkan ekspektasi rate of return tidak dapat tercapai. Eva negative juga menunjukkan bahwa perusahaan belum efisien dalam aktivitas mengelola sumber daya yang dimiliki, dengan demikian perusahaan dapat dikatakan belum dapat meningkatkan kemakmuran pemegang sahamnya.

\section{Ringkasan Perhitungan EVA}

Dari ketiga perusahaan telekomunikasi dapat dilihat kinerja perusahaan tersebut dengan EVA, ada yang menghasilkan nila EVA positif ada pula yang nilai EVA nya negative. PT Telekomunikasi Indonesia selama periode 2005-2009 dapat mencetak EVA positif, hal ini disebabkan karena pertumbuhan industry telekomunikasi cukup baik, sehingga meningkatkan permintaan akan jasa-jasa infokom. Kondisi tersebut dapat dilihat pula dari pencapaian laba bersih PT Telkom yang jauh melampaui laba bersih dari PT Indosat Tbk dan PT Bakrie Telecom Tbk, dimana biaya bunga yang di tanggung oleh PT Telkom hampir sama dengan PT Indosat dan PT Bakrie.

PT Indosat Tbk dan PT Bakrie Telecom Tbk selama periode 2005-2009 tidak berhasil menghasilkan nilai EVA positif. Kedua perusahaan itu menghasilkan EVA negative selama periode penelitian. Pertumbuhan industry telekomunikasi dan dampak krisis ekonomi global dan perang tariff pada tahun 2008-2009 mempengaruhi pencapaian EVA kedua perusahaan tersebut. Laba bersih yang menurun terhitung tahun 2007 sampai dengan 2008 dan meningkatnya biaya bunga yang berarti meningkatnya hutang jangka panjang semakin membuat kedua perusahaan ini sulit untuk membukukan EVA positif. Sementara dalam memenuhi kebutuhan pertumbuhan teknologi telekomunikasi kemungkinan perusahaan akan melakukan banyak sekali investasi agar dapat tetap bersaing dengan perusahaan lainnya. Jika perusahaan memperoleh EVA negative karena melakukan investasi dan ada kemungkinan akan memberikan dampak besar terhadap kinerja perusahaan di masa mendatang, hal ini tidak bisa di bilang buruk, tapi disarankan agar semua upaya investasi haruslah 
ditujukkan untuk mencapai EVA positif. Strategi yang bisa dilakukan untuk memperbaiki kinerja antara lain meningkatkan pertumbuhan pendapatan, disertai dengan efisiensi (cost control), optimalisasi pemanfaatan asset (manage asset utilization) dan optimalisasi biaya modal (cost of capital).

\section{KESIMPULAN DAN SARAN}

\section{Kesimpulan}

Dari hasil pengumpulan data, pengolahan data, dan analisa yang dilakukan maka dapat ditarik kesimpulan sebagai berikut :

1. Dilihat dari laporan keuangannya, ketiga perusahaan telekomunikasi dapat menghasilkan laba usaha setiap tahunnya.

2. Setelah dilakukan perhitungan EVA (Economic Value Added), diperoleh hasil bahwa dari ketiga perusahaan telekomunikasi yang dijadikan objek penelitian hanya PT Telekomunikasi Indonesia tbk saja yang dapat menghasilkan EVA positif, sementara PT Indosat Tbk dan PT Bakrie Telecom Tbk menghasilkan EVA yang negatif.

3. Nilai EVA negatif yang diperoleh PT Indosat Tbk dan PT Bakrie Telecom Tbk, disebabkan oleh beberapa faktor, antara lain :

a. Pada akhir tahun 2005 terjadi kenaikan harga BBM yang amat signifikan, diikuti inflasi dan naiknya tingkat suku bunga yang berpengaruh pada daya beli masyarakat, yang berdampak pada pertumbuhan pendapatan yang tidak mengalami kenaikan secara signifikan.

b. Meningkatnya biaya modal dan biaya operasional kedua perusahaan.

c. Dampak krisis financial global tahun 2008 berpengaruh terhadap aktivitas usaha perusahaan yang akhirnya menurunkan nilai saham kedua perusahaan.

d. Dampak perang tarif antar perusahaan telekomunikasi dimana tarif telepon menjadi lebih rendah dan turunnya call rate sambungan jarak jauh mempengaruhi pendapatan usaha perusahaan telekomunikasi.

\section{Saran}

Saran yang dapat diberikan untuk investor dan perusahaan telekomunikasi yang terdaftar di BEI dalam memperbaiki kinerja keuangannya, antara lain :

1. Perusahaan perlu mengkaji salah satu manfaat EVA, yaitu adanya informasi tentang aliran kas bersih (netto) yang merupakan sisa laba bersih yang terbebas penggunaannya terhadap klaimklaim lainnya

2. Kajian EVA dalam pengukuran kinerja perusahaan mengindikasikan bahwa laba bersih setelah pajak masih perlu ditindak lanjuti dengan sisa laba akhir.

3. Bagi perusahaan yang menghasilkan EVA negatif diharapkan untuk meningkatkan prestasinya dan secepat mungkin memperbaiki kinerjanya dengan memperhatikan perubahaan yang terjadi di pasar saham, karena hal itu akan mempengaruhi pandangan inverstor terhadap perusahaan.

\section{DAFTAR PUSTAKA}

Arifin, Johar Cara Cerdas Menilai Kinerja Perusahaan Berbasis Komputer: Elek Media Komputindo

Asnawi, Said Kelana \& Wijaya, Chandra. (2005). Riset Keuangan : Pengujian-pengujian empiris : Gramedia Pustaka Utama.

DeMello, Jim, (2006), Kasus-kasus Keuangan, Edisi 2, Jakarta: Salemba Empat. Febrian, Erie \& Rr. Iramani. (2005). Financial Value added Suatu Paradigma Dalam Pengukuran Kinerja dan Nilai Tambah Perusahaan.Jurnal Ekonomi Akuntansi, Fakultas Ekonomi-Universitas Kristen Petra

Harahap, Sofyan Syafri. (2010). Analisis Kritis atas Laporan Keuangan, Jakarta : Rajawali Pers.

Helfert, A Erich, (1991). Analisis Laporan Keuangan, Jakarta, Erlangga.

Panggabean, Raja Lambas J(2005), Analisis Perbandingan Korelasi EVA dan ROE terhadap Harga Saham LQ 45 di Bursa Efek Jakarta, Jurnal Manajemen dan Bisnis Sriwijaya Vol.3 No.5 Juni 2005. 
Munawir. S. (2002). Analisa Laporan Keuangan : Penerbit Liberty, Yogyakarta. Pradhono, Christiawan, Jogi Yulis. Pengaruh Economic Value Added, Residual Income,

Earnings dan Arus Kas Operasi Terhadap Return Yang Diterima Oleh Pemegang Saham. Jurnal Ekonomi Akuntansi, fakultas Ekonomi, Univ. Kristen Petra.

Sasongko, Noer \& Walandari, Nila. (2006). Pengaruh EVA dan Rasio-rasio Profitabilitas Terhadap Harga Saham, Fakultas Ekonomi Universitas Muhammadiyah Surakarta.

Sefcho Rizal, MM Ratna Sari, Analisis Economic Value Added (EVA) Dalam Hubungannya Dengan Harga Saham Pada Perusahaan Jasa Transportasi Yang Listing di Bursa Efek Jakarta Periode 2003-2005, ejournal Unud.ac.id

Taufiq, Pengaruh PendekatanTradisional Accounting Dan Economic Value Added Terhadap Stock Return Perusahaan Sektor Perbankan Di PT Bursa Efek Jakarta. Jurnal Manajemen dan Bisnis Sriwijaya Vol.5 No.10 Juni 2007

Tunggal, Amin Wijaya. (2008). Pengantar Konsep Economic Value Added (EVA) dan Value-Based Management (VBM): Harvindo

Utomo, Lisa Linawati.(1999). Economic Value Added Sebagai Ukuran Keberhasilan Kinerja Manajemen Perusahaan, Jurnal Akuntansi dan Keuangan Vol. 1, No.1, Mei 1999 : 28-42, Universitas Kristen Petra

Young, David S dan O'Byrne, Stephen F. (2001). EVA dan Manajemen berdasarkan Nilai ::Penerbit Salemba Empat, Jakarta. www.idx.co.id 